\title{
Comparative Economic Investigation Options for Liquefied Petroleum Gas Production from Natural Gas Liquids
}

\author{
A. B. Raheem ${ }^{1,2}$, A. Hassan ${ }^{1}$, S. A. Samsudin $^{1}$, Z. Z. Noor ${ }^{1}$, A. Adebobajo ${ }^{2}$ \\ ${ }^{1}$ Faculty of Chemical Engineering, Universiti Teknologi Malaysia, Johor Bahru, Malaysia \\ ${ }^{2}$ Department of Chemical Engineering, University of Port Harcourt, Port Harcourt, Nigeria
}

\section{Email address:}

rahbol_debven@yahoo.com (A. B. Raheem)

\section{To cite this article:}

A. B. Raheem, A. Hassan, S. A. Samsudin, Z. Z. Noor, A. Adebobajo. Comparative Economic Investigation Options for Liquefied Petroleum Gas Production from Natural Gas Liquids. American Journal of Chemical Engineering. Special Issue: Developments in Petroleum Refining and Petrochemical Sector of the Oil and Gas Industry. Vol. 3, No. 2-1, 2015, pp. 55-69. doi: 10.11648/j.ajche.s.2015030201.17

\begin{abstract}
There is new trend in the value of oil and gas in the world, with the value of Liquefied Petroleum Gas (LPG) soaring higher. It is due to its uses as a potential fuel in the several parts of the world, its demand in the petrochemical industries for plastics and automotive composites productions, and other uses. These results in steadily increases in price. There is also increase in volume of feed gas, which demands efficient LPG processing and recovery technology. This paper mainly focuses on comparative economic investigation options for Liquefied Petroleum Gas plant, which processes feed from natural gas wells and dehydrating units to produce Liquefied Petroleum Gas along with natural gasoline having a higher value as separate product. Recovery of LPG is possible but raises both the initial cost of plant and operational cost considerably. The value of LPG recovered should be high enough to widen the operating margins between the processing costs and the market price for which the recovered liquids can be sold. Therefore, the most economic means of extracting this product must be used. This was done using two alternatives; the Conventional Fractionation process and Single column overhead recycle process (SCORE). Both alternatives were simulated with Hysys and are analyzed based on product recovery level, energy required and fixed capital cost. There are two feeds to the plant, one from the natural gas wells and the other from dehydrating units of natural gas processing plants with a total flow rate of 6.99 MMSCFD. Analysis of result from modeling shows that Single column overhead recycle process has a total product recovery of $97.2 \%$ while Conventional fractionation process has a total recovery of $88.5 \%$, the require energy margin between the alternatives is about $38.9 \%$ in favor of conventional process and the fixed capital cost is in the favor of Single column process. Sensitive to choosing the most economic option of LPG recovery between the conventional process and SCORE process is the recovery level of LPG from each of the options, total energy required and the cost of the equipment. From the analysis, it shows that, it is more economical to use the Single column overhead recycle process, as compared to conventional fractionation process.
\end{abstract}

Keywords: Liquefied Petroleum Gas Plant, Dehydrating Units, Conventional Fractionation Process, Single Column Overhead Recycle Process, Hysys

\section{Introduction}

Liquefied petroleum gas, also called LPG, GPL, LP Gas, liquid petroleum gas or simply propane, is a flammable mixture of hydrocarbon gases used as a fuel in heating appliances and vehicles. It is increasingly used as an aerosol propellant and a refrigerant, replacing chlorofluorocarbons in an effort to reduce damage to the ozone layer. When specifically used as a vehicle fuel it is often referred to as auto gas $[1,2]$.

The purification of natural gas gotten from heavier hydrocarbon, in natural gas processing plants, require several stages of separation and fractionation. The separated liquid product obtains is named as natural gas liquids (NGL). The unrefined NGL is sent to LPG recovery plant to separate LPG that contains iso-propane $\left(\mathrm{i}-\mathrm{C}_{3}\right)$ and iso-butane $\left(\mathrm{i}-\mathrm{C}_{4}\right)$ from stabilized NGL $\left(\mathrm{C}_{5}^{+}\right)[3,4]$. The values and prices of both products are very high in the market due to their domestic and other usefulness's. Varieties of LPG bought and sold include mixes that are primarily propane $\left(\mathrm{C}_{3} \mathrm{H}_{8}\right)$, primarily butane $\left(\mathrm{C}_{4} \mathrm{H}_{10}\right)$ and, most commonly, mixes including both propane and butane, depending on the season - in winter more propane, in summer more butane [1]. 
High demand of LPG as fuel in many parts of the World due to aforementioned uses, its availability (more gas wells) and price increase against the oil price makes it require more focus for more and effective production methods.

In this work, LPG recovery plant is simulated using commercial software (Hysys) to investigate the process economy. The use of conventional fractionation process as an alternative to single column overhead recycle process (SCORE) is discussed in order to find the most economic process for LPG production.

\section{Properties of Liquefied Petroleum Gas}

It is an established fact that Liquefied Petroleum Gas (LPG) is a mixture of hydrocarbon gases, which consists mainly of propane and butane. Its composition depends majorly on its source, processing principles and the season it is produced [5]. LPG processed in the winter always have record of containing more propane, whereas it contains more butane in the summer. At room temperature of say, $25^{\circ}$ to $27{ }^{\circ} \mathrm{C}$, propane vapor pressure is 9.36 bar while butane vapor pressure is 2.44 bar. LPG is normally odorless, colorless, non-toxic and ready to explode at a slight raised temperature. The peculiar distinctive pungent odour that it has is due to addition of odorizing agent such as ethanethiol, in other to reduce the danger of explosion that may arise due to undetected leaks from cargoes, pipes or tanks. LPG calorific value is $94 \mathrm{MJ} / \mathrm{m}^{3}$ (equivalents to 26.1 $\mathrm{kWh}$ ), which is higher than that of natural gas of $38 \mathrm{MJ} / \mathrm{m}^{3}$ (equivalents to $10.6 \mathrm{kWh}$ ) [5]. The properties of LPG are tabulated in Table 1.

Table 1. Properties of LPG [6].

\begin{tabular}{ll}
\hline Name of the Property & Value for LPG \\
\hline Freezing Point & $-187^{\circ} \mathrm{C}$ \\
Specific Gravity & 0.588 \\
Vapour Pressure at $38{ }^{\circ} \mathrm{C}$ & $1212 \mathrm{KPa}$ \\
Heat Content & $50221 \mathrm{KJ} / \mathrm{KG}$ \\
\hline
\end{tabular}

It is of interest to shows that recovery of LPG is possible but raises both the initial cost of plant and operational cost considerably. In order to achieve this, it is pertinent that the value of LPG recovered should be high enough to widen the operating margins between the processing costs and the market price for which the recovered liquids can be sold. Therefore, the most economic means of extracting this product must be used.

The utmost aim of this work is to investigating the economic process of LPG production from NGL using two different alternatives. In order to help the already established and new industrial company have a realistic view of LPG recovery process and enhance their decisions as to making investment in this sector.

This research identifying an economic or optima process of LPG recovery to encourage both already established and new industrial company from all over the world to invest in this sector, thus consumption of it will increase throughout the world as a result of its wide availability and most importantly, our environment will be protected because of its clean-burning property.

Two alternative methods of extracting LPG from NGL were studied in this work and they are; Single Column Overhead Recycle process (SCORE) and Conventional Fractionation Process. Both methods were modelled using the commercial process software (Hysys) and the results from modelling were compared. This method enabled the more economic option stands out on its merit owing to the result of the modeling.

The two major processes key operating measures, and benefits of the processes to investigate their recovery and economy efficiency performance of the LPG from NGL will be discussed further in the remaining part of this paper.

\subsection{LPG Recovery Technology}

Several technologies have been developed in order to extract LPG from natural gas liquids (NGL). Also, researches coupled with simulations have been done to find the most optimum and economic process. The recovery process can be categorized mainly into two groups namely; conventional and advance processes. Example of conventional fractionation process is shown in Figures 1, while examples of advance LPG recovery processes are shown in Figures 2, 3, 4, and 5.

\subsection{Conventional Fractionation Process}

There are four (4) columns used in this conventional process. First stage of LPG extraction from NGL is De-ethanizer. In this column, methane and ethane will be separated at the top of the column as vapour phase. The heavier hydrocarbons $\left(\mathrm{C}_{3}^{+}\right)$flows at the bottom in liquid phase for next entering the Debutanizer column. In this column, propane and butane are separated and go to the top of the column, while the stabilized natural gas liquid $\left(\mathrm{C}_{5}{ }^{+}\right)$flows at the bottom. In order to obtain pure specified propane product, propane and butane are separated in De-propanizer Column. Propane goes to the top and butane goes to the bottom. Then finally, n-butane and isobutene are separated in butane splitter to get the specified products [2]. A simplified conventional fractionation process is shown in Figure 1.

\subsection{Advance LPG Recovery Technology}

Since 1970's and till now, Ortloff Engineering have developed several processes for LPG recovery that are very efficient and more $\mathrm{CO}_{2}$ tolerant. Some of these processes includes Gas sub-cooled process (GSP), Overhead recycle process (ORH), Recycle split-vapour process (RSV), Single column overhead recycle process (SCORE), LNG fractionation process (LFP) and some others [7, 8, and 9].

\subsubsection{Gas Sub-cooled Process (GSP)}

In this process, a portion of the feed gas that is after vaporization is condensed and sub-cooled flashed down to the tower operating pressure, and supplied to the tower as its top feed. The remainder of the feed gas is also expanded to lower pressure by using turbo expander for vapour streams and thereafter fed to the tower at one or more intermediate feed points. The cold liquids supplied to the top of the tower act as 
reflux, contacting and rectifying the vapour leaving the expander by absorbing the ethane-plus components for recovery in the bottom product [7, 10, and 11]. This gas sub-cooled process is showing in Figure 2.

\subsubsection{Overhead Recycle Process (OHR)}

This process has often been used instead of GSP for LPG recovery although it typically employ a two-column configuration, this process in essence withdraws a vapour stream from an intermediate point in the composite distillation tower that is then condensed and used as reflux for the upper portion of the composite tower. This produces cold liquids to contact and rectify the vapour leaving the expander, absorbing the propane-plus components for recovery in the bottom product from the second column. This process provides more efficient recovery of propane and heavier hydrocarbons than the GSP design [7, 10, and 11]. This is shown in Figure 3.

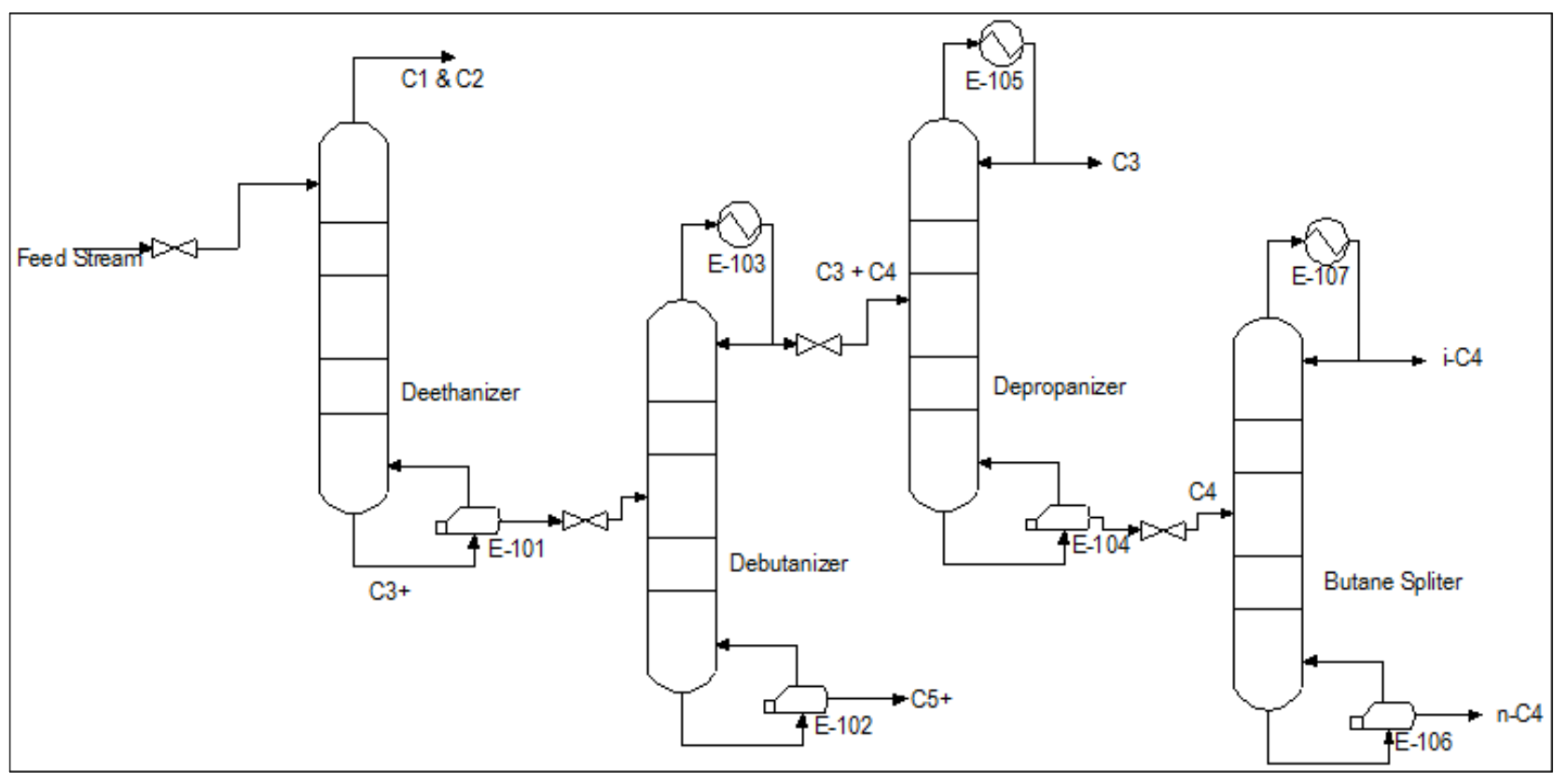

Figure 1. Simplified Conventional Fractionation process [4]

\subsubsection{Recycle Split-Vapour Process (RSV)}

The RSV process uses the split-vapour feed to provide the bulk ethane recovery in the tower. The methane reflux stream for the tower is produced by withdrawing a small portion of the recompressed residue gas, condensing and sub-cooling it, then flashing it down to tower pressure and supplying it as the top feed. The higher pressure of this methane stream allows the tower overhead gas to be used to provide the condensing and sub-cooling; so that the split-vapour feed can be supplied directly to the tower. RSV process is suited to both ethane recovery and ethane rejection operation, and can switch easily between the two operating modes as market prices change. RSV also has better $\mathrm{CO}_{2}$ tolerance. [7, 12]. Figure 4 is showing a typical recycle slit-vapour process.

\subsubsection{Single Column Overhead Recycle Process (SCORE)}

Ortloff's Single Column Overhead Recycle (SCORE) process is a cryogenic gas processing technology suited to the recovery of propane and heavier hydrocarbons from a natural gas stream. The SCORE design is an enhancement of Ortloff's popular Overhead Recycle Process, combining extremely cooling to the inlet gas and is then fed to the tower in the bottom (stripper) section [15]. It has high propane recovery with high efficiency [13]. Initial gas stream enters the gas/gas exchanger where the gas is cooled by heat exchange with the residue gas, the cold separator liquids, and the side re-boiler stream, then enters the cold separator. The vapours from the cold separator are work-expanded to provide cooling for the process [14]. The 2-phase expander outlet stream is fed to the tower at the bottom of the top (absorber) section. The liquid from the cold separator is used to provide cooling to the inlet gas and is then fed to the tower in the bottom (stripper) section [15].There is a side vapour draw below the expander feed tray. This vapour draw is the vapour coming up from the bottom section of the tower, and contains methane and ethane that can be used as reflux to absorb the heavy hydrocarbons from the expander vapour. The vapour draw is partially condensed as it is cooled by the tower overhead stream, then fed to a reflux accumulator to separate liquid for reflux to the absorber and stripper sections of the tower. There is also a side liquid draw below the expander feed point that is used to provide inlet gas cooling. The side liquid draw is similar to a side re-boiler, except that the liquids are returned to the tower several stages below the draw stage. Finally the desired product is drawn at the bottom of the stripper [7,10, and 11]. This is shown in Figure 5.

SCORE Preference to Others: Its preference over others is simply because its propane recovery ability is very high and it is between 97 to $99 \%$ or higher with maximum efficiency, while rejecting ethane which are of great importance. It can operate in a partial ethane recovery mode by adjusting the quantity of heat input to the column, to have ethane recovery 
limited to $40 \%$ if ethane recovery is desired. It requires no additional equipment for moderate ethane recovery. It has high economic value for its ability to operate in either ethane recovery or rejection modes for extended periods.

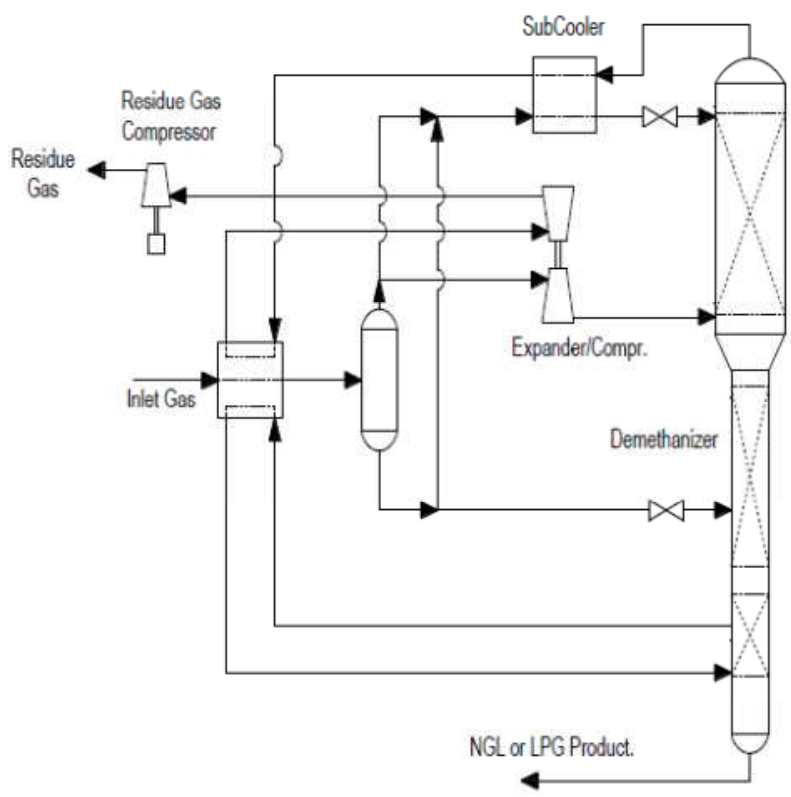

Figure 2. A typical Gas Sub-cooled Process [5]

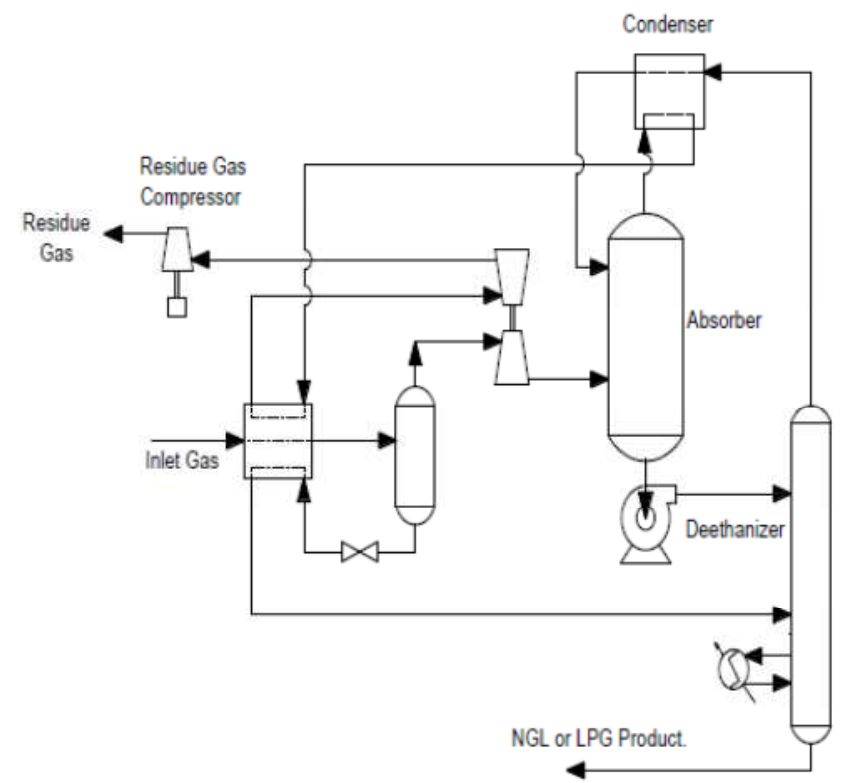

Figure 3. A typical overhead recycle process [5]

It has better $\mathrm{CO}_{2}$ tolerance. It can be switched over to Gas Sub-cooled Process (GSP) mode. It can also accommodate wider range of natural gas composition and inlet conditions, with pressure above 600 PSI preferred for natural gas streams, but can still accommodate lower pressures. It normally produces a mixed LPG product stream with product specification of maximum ethane in propane liquid. Whereas in Gas Sub-cooled Process (GSP) mode, a mixed NGL product stream is produced with product specification of a maximum methane in ethane liquid.

\subsubsection{LNG Fractionation Process}

With the dramatic increase in LNG production and shipping worldwide, increased attention is being focused on the processing of these products on the receiving end. In industrialized locations it is desirable to extract the lighter hydrocarbons, to recover a valuable saleable product and also control the heating value of the pipeline gas $[16,17]$. A better method for controlling the delivery heating value is to recover LPG by integrating the recovery step into the vaporization step, eliminating the need for recompression and taking advantage of the refrigeration available in the LNG [18]. This provides the lowest capital and operating cost alternative for controlling heating value, while also providing a significant additional revenue stream [19]. This is shown in Figure 6.

The different processes designs are shown in the Figures 1 to 6 in order to know the required unit for each design. It is based on the units involves that the simulation was done.

\subsection{Basis of Work}

The bases of this work are; feed stream condition, compositions and product specification [2].

\subsection{Feed Streams}

Feed stream used for the simulation are given in the Table 2 . The compositions are in mole fraction.

Table 2. Feed Composition [4].

\begin{tabular}{|c|c|c|}
\hline Property & Feed 1 [from well] & Feed 2 [from dehydration unit] \\
\hline Temperature & $25^{\circ} \mathrm{C}$ & $25^{\circ} \mathrm{C}$ \\
\hline Pressure & 30 bar & 30 bar \\
\hline Mass flow rate & 25 ton $/ \mathrm{hr}$. & 8 ton $/ \mathrm{hr}$. \\
\hline \multicolumn{3}{|l|}{ Composition } \\
\hline $\mathrm{CH}_{4}$ & 0.097 & 0.130 \\
\hline $\mathrm{C}_{2} \mathrm{H}_{6}$ & 0.029 & 0.080 \\
\hline $\mathrm{C}_{3} \mathrm{H}_{8}$ & 0.035 & 0.100 \\
\hline $\mathrm{i}-\mathrm{C}_{4}$ & 0.018 & 0.055 \\
\hline $\mathrm{n}-\mathrm{C}_{4}$ & 0.028 & 0.113 \\
\hline $\mathrm{i}-\mathrm{C}_{5}$ & 0.026 & 0.104 \\
\hline $\mathrm{n}-\mathrm{C}_{5}$ & 0.025 & 0.091 \\
\hline $\mathrm{n}-\mathrm{C}_{6}$ & 0.064 & 0.122 \\
\hline $\mathrm{n}-\mathrm{C}_{7}$ & 0.090 & 0.110 \\
\hline $\mathrm{n}-\mathrm{C}_{8}$ & 0.150 & 0.072 \\
\hline $\mathrm{n}-\mathrm{C}_{9}$ & 0.110 & 0.020 \\
\hline $\mathrm{n}-\mathrm{C}_{10}$ & 0.090 & 0.003 \\
\hline $\mathrm{C}_{11}$ & 0.079 & 0.000 \\
\hline $\mathrm{C}_{12}$ & 0.071 & 0.000 \\
\hline $\mathrm{C}_{13}$ & 0.031 & 0.000 \\
\hline $\mathrm{C}_{14}$ & 0.023 & 0.000 \\
\hline $\mathrm{C}_{15}$ & 0.018 & 0.000 \\
\hline $\mathrm{C}_{16}$ & 0.014 & 0.000 \\
\hline $\mathrm{H}_{2} \mathrm{O}$ & 0.002 & 0.000 \\
\hline
\end{tabular}




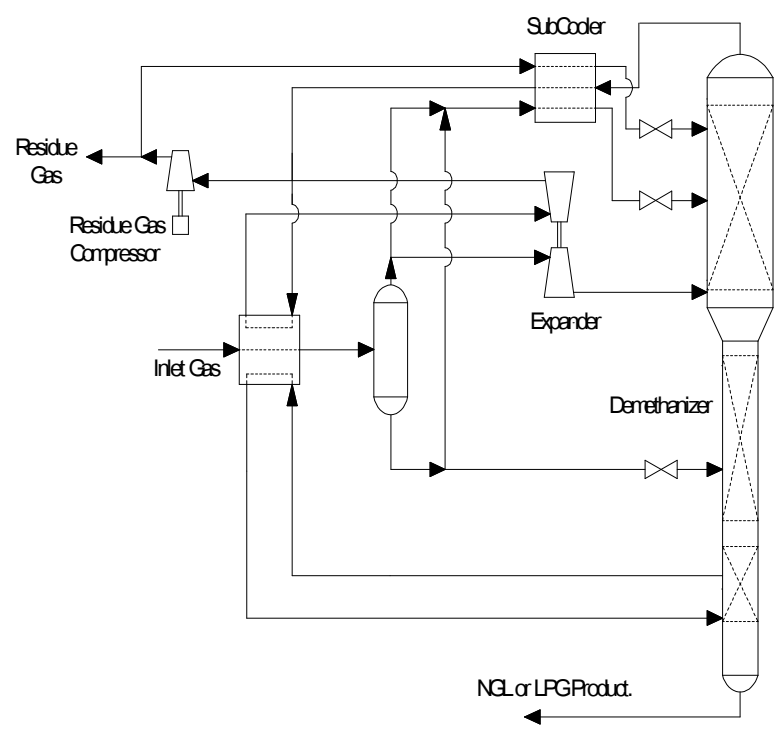

Figure 4. A typical Recycle Split-Vapour process [7]

\subsection{Product Specifications}

Product specifications are defined based on commercial products in LPG market [20]. Specifications of LPG products are taken from OPIC and Argus Americans Methodology [21].
LPG specifications to work with in this project are given in the Table 3. The product specification above will be used as initial basis to model the simulation. However, final decision about the product will be made after analysis of the economics of the research.

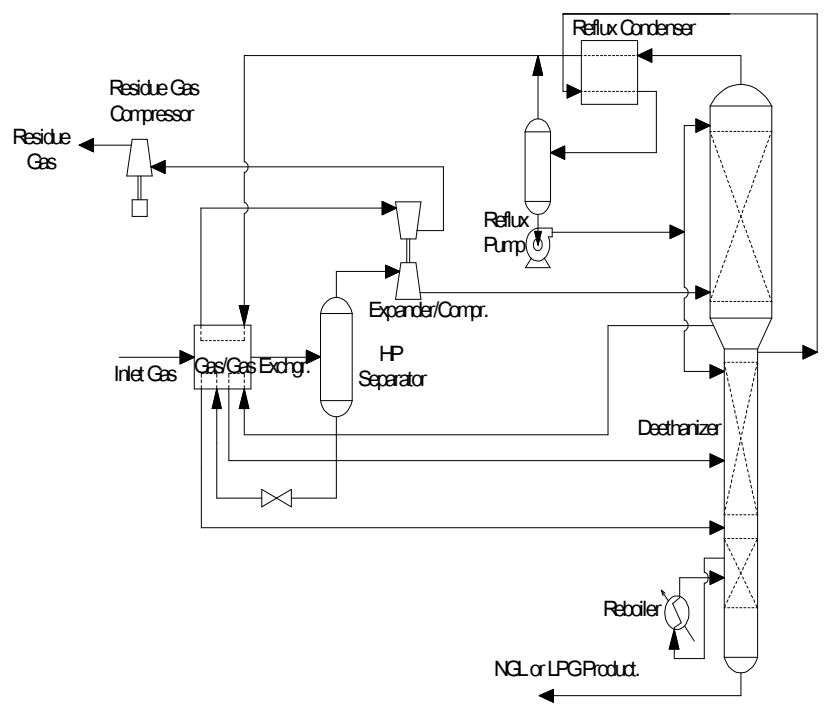

Figure 5. A Typical Single Column Overhead Recycle process [7].

Table 3. Product Specifications [21].

\begin{tabular}{|c|c|c|c|c|c|c|}
\hline No. & Product & $\%$ Minimum & Other Components & $\%$ Maximum & Relative Density & Price (\# / Gal) \\
\hline \multirow{4}{*}{1} & \multirow{4}{*}{$\mathrm{n}$ - Butane } & \multirow{4}{*}{94} & i-butane & 6 & \multirow{4}{*}{0.584} & \multirow{4}{*}{1.54661} \\
\hline & & & Propane & 0.35 & & \\
\hline & & & Pentane & 1.5 & & \\
\hline & & & Olefin & 0.35 & & \\
\hline 2 & i-Butane & 96 & $\begin{array}{l}\text { n-butane } \\
\text { Propane }\end{array}$ & $\begin{array}{l}4 \\
3\end{array}$ & 0.563 & 1.60083 \\
\hline 3 & Propane & 90 & Propylene & 5 & 0.507 & 1.17594 \\
\hline 4 & $\mathrm{C}_{5}^{+}$ & & & & 0.664 & 1.90315 \\
\hline 5 & Field Grade Butane & & $\begin{array}{l}\text { i-butane } \\
\text { n-butane }\end{array}$ & $\begin{array}{l}35 \\
65\end{array}$ & & 1.4383 \\
\hline
\end{tabular}

\section{Methodology}

In this project, the comparative economic investigation options for LPG recovery is done by modeling Conventional Fractionation process and Single Column Overhead Recycle process using commercial simulation software (Hysys). The method used in this work is based on the procedure derived from the principle of three concepts: (1) product recovery; based on the simulation, the product recovery of the two options considered were evaluated. (2) Equipment duty; based on the simulation, the energy required of the two options considered were investigated and accounted for. (3) Fixed capital cost; equipment cost were done using the specifications of the equipment's, quote from suppliers shows that almost the same price list is used for all the equipment. Working capital of $3 \%$ of fixed capital can be added to have the total capital, based on the design standard. Although, operating cost, direct cost, utility cost and operating labor cost were not considered, because they depend on the capacity of the plant which this work is silence on, as we assumed it to be relatively the same for the two options. Fixed capital cost is enough to show the needed difference. Investment analysis of profitability, internal rate of return (IRR), net present value (NPV) and pay-back period were not done. This method will enable the most economic option stand out on its merit owing to the result of the modeling.

\subsection{Conventional Fractionation Process}

Process Flow -There are four (4) columns used in this conventional process. First stage of LPG extraction from NGL is de-ethanizer. In this column, methane and ethane will be separated at the top of the column as vapor phase. The heavier hydrocarbons $\left(\mathrm{C}_{3}{ }^{+}\right)$will flow at the bottom in liquid phase for next entering the debutanizer column. In this column, propane and butane are separated and go to the top of the column, while the stabilized natural gas liquid $\left(\mathrm{C}_{5}^{+}\right)$flows at the bottom. In order to obtain pure specified propane product, 
propane and butane are separated in de-propanizer column. Propane goes to the top and butane goes to the bottom. Then finally, n-butane and isobutene are separated in butane splitter to get the specified products.

Parameters - Simulating the LPG extraction process flow above is not as simple as the description, especially to converge the distillation column with Hysys. The parameters below should be considered in order to find a good result of simulation and the process as well as minimize the errors of the calculation.

- Operating pressure of the column

- Temperature of top product - avoid using refrigerant

- Number of stages

- Column specification

- Temperature profile at each tray

- Product specification

- Reboiler duty

Modeling- Generally, the process modeling for Conventional LPG extraction with Hysys is divided into five (5) main sections. The sections are; feed conditioning, de-ethanizer, de-butanizer, de-propanizer and butane splitter. The additional condenser and reboiler are also explained separately. Each section will be described step by step.

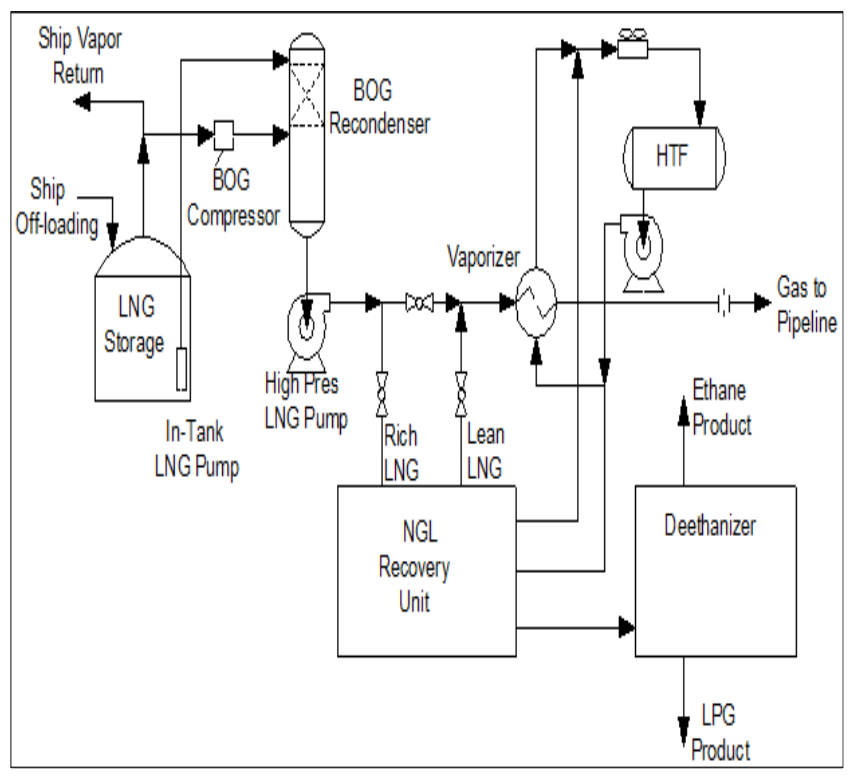

Figure 6. LNG Fractionation Process Flow Diagram [22]

\subsection{Feed Conditioning}

As mentioned in the project basis, there are two (2) feed streams of NGL. Both streams have the same condition of pressure and temperature that is 30 bar and $25^{\circ} \mathrm{C}$, but different compositions and mass flow rates.

First step of the LPG extraction process is feed conditioning before entering the de-ethanizer column. The most simple and economic means of conditioning this kind of stream is to mix both feed stream, expand the mixed feed and enter the de-ethanizer column without using any separator. The operating conditions of the mixed stream are shown in Table 4.
Table 4. Mixed feed

\begin{tabular}{ll}
\hline Operating Conditions & Value \\
\hline Pressure (bar) & 30 \\
Temperature $\left({ }^{\circ} \mathrm{C}\right)$ & 24.87 \\
Molar flow (MMSCFD) & 6.989 \\
\hline
\end{tabular}

\subsubsection{De-Ethanizer}

The next thing to do after defined stream connection in de-ethanizer properties specification is to select the operating pressures at the top and the bottom of the column. As initial guess, 26.9 bar pressure was used based on reference. Since the feed pressure is 30 bars, expansion valve is added in order to meet the operating pressure of the column. There will be no condenser that is used at the overhead column stream in order to minimize cost so only one column specification needs to be defined to converge the column. The operating pressure has to be selected so that most methane and ethane flow to overhead column and keep propane and heavier hydrocarbons as the bottom product. The lower the pressure the more the vapour phase.

Practically, some trials have to be done to find the best result in selecting the column specification and number of stages bearing in mind their respective costs. The more the number of stages means the better the separation process. In the other hand, more number of stages means higher column is required and the cost will be more expensive. The simulation is continued to modeling the debutanizer column. This is shown in Table 5.

Table 5. De-ethanizer

\begin{tabular}{ll}
\hline Operating Conditions & Value \\
\hline $\begin{array}{l}\text { Pressure of the Top Stage and Bottom Stage } \\
\text { (bar) }\end{array}$ & 18,26 \\
$\begin{array}{l}\text { Temperature of the Top Stage and Bottom Stage } \\
\left({ }^{\circ} \mathrm{C}\right)\end{array}$ & $36.05,248$ \\
Number of Stages & 18 \\
Column Specification & Bottom Product Rate \\
Reboiler Duty $(\mathrm{KW})$ & 5449 \\
\hline
\end{tabular}

\subsubsection{De-Butanizer}

Both condenser and reboiler properties specifications are used in simulating de-butanizer. Basically, the steps in simulating the debutanizer column are almost the same like de-ethanizer. The differences are in selecting the column specifications. Since both condenser and reboiler specifications are used, there are 2 column specifications to be defined in order to converge the column.

In this case, components recovery of the top product is selected as column specification. It is expected to separate propane and butane at the top and heavier hydrocarbons at the bottom. Even though most propane and butane can be recovered as the top product, there is one specification that should be considered, that is, reboiler duty. It is possible to have $99.99 \%$ of propane and butane at the top, but more reboiler duty will be required. Thus, the fraction of components recovery should be selected by considering minimum reboiler duty in order to minimize the cost for the steam. It is shown in Table 6. 
Table 6. Debutanizer

\begin{tabular}{ll}
\hline Operating Conditions & Value \\
\hline $\begin{array}{l}\text { Pressure of the Top Stage and } \\
\text { Bottom Stage (bar) }\end{array}$ & 16,17 \\
$\begin{array}{l}\text { Temperature of the Top Stage } \\
\text { and Bottom Stage }\left({ }^{\circ} \mathrm{C}\right)\end{array}$ & $81.04,236$ \\
$\begin{array}{l}\text { Number of Stages } \\
\text { Column Specification }\end{array}$ & 19 \\
Reboiler Duty (KW) & Component Recovery and Boil up Ratio \\
\hline
\end{tabular}

\subsubsection{De-Propanizer}

Both condenser and reboiler are used in simulating the de-propanizer. In this column, propane liquid is produced as overhead product and butane as bottom product. It is simpler simulating this column since it only has two compositions in the feed. Components recovery is also used as column specification. There is no significant reboiler duty difference in changing the recovery fraction value. Selecting operating pressure and number of stages are also done using initial guess value from reference. Some trials still have to be done to find the optimum value. This is shown in Table 7. Hysys conventional depropanizer result is shown in Table 24 in the appendix.

Table 7. De-propanizer

\begin{tabular}{ll}
\hline Operating Conditions & Value \\
\hline Pressure of the Top Stage and & 9,10 \\
$\begin{array}{l}\text { Bottom Stage (bar) } \\
\text { Temperature of the Top Stage }\end{array}$ & $23.49,81.02$ \\
and Bottom Stage $\left({ }^{\circ} \mathrm{C}\right)$ & 19 \\
Number of Stages & Component Recovery and Boil up Ratio \\
Column Specification & 129.2 \\
\hline
\end{tabular}

\subsubsection{Butane Splitter}

Butane from de-propanizer column is next separated into i-butane and n-butane in butane splitter column. It is typically the same as the de-propanizer column as shown in Figure 3.9. Components recovery is still used as column specification. But it is more difficult than two previous columns to meet the products specification for $n$-butane and i-butane, since it is very sensitive with changing value of component recovery. So that some trials have to be done to select the optimum components recovery value for both n-butane and i-butane in order to meet the specification of the product. Selecting operating pressure and number of stages are still done using initial guess value from reference. It is shown in Table 8 . Hysys result for conventional butane splitter is shown in Table 25 in the appendix.

Table 8. Butane Splitter

\begin{tabular}{ll}
\hline Operating Conditions & Value \\
\hline $\begin{array}{l}\text { Pressure of the Top Stage and } \\
\text { Bottom Stage (bar) }\end{array}$ & 4,5 \\
$\begin{array}{l}\text { Temperature of the Top Stage } \\
\text { and Bottom Stage }\left({ }^{\circ} \mathrm{C}\right)\end{array}$ & $0.63,63.14$ \\
$\begin{array}{l}\text { Number of Stages } \\
\text { Column Specification }\end{array}$ & 19 \\
Reboiler Duty $(\mathrm{KW})$ & Component Recovery and Boil up Ratio \\
\hline
\end{tabular}

\subsection{Reboiler and Condenser}

Reboiler and condenser are parts of the columns. Reboiler is used to supply heat into the column, so that the lighter hydrocarbons will be vaporized and go up to the top stage. Steam is used to heat up a part of bottom product and recycle it into the column. Meanwhile, condenser is used to condense the overhead vapor so the liquid product will be produced which partially recycled into the column as reflux.

\subsection{Single Column Overhead Recycle Process}

\subsubsection{Process Flow}

Feed gas stream from mixer enters the LNG exchanger where the gas is cooled by heat exchange with the residue gas, the cold separator liquids, and the side reboiler stream, then enters the cold separator. The vapour from the cold separator is work-expanded and the 2-phase expander outlet stream is fed to the tower at the bottom of the top (absorber) section. The liquid from the cold separator is used to provide cooling to the inlet gas and is then fed to the tower in the bottom (stripper) section.

There is a side vapour draw below the expander feed tray. This vapour draw is the vapour coming up from the bottom section of the tower. The vapour draw is partially condensed as it is cooled by the tower overhead stream, then fed to a reflux accumulator to separate liquid for reflux to the absorber and stripper sections of the tower. There is also a side liquid draw below the expander feed point that is used to provide inlet gas cooling, the liquids are returned to the tower several stages below the draw stage. Finally the desired product is drawn at the bottom of the stripper.

\subsubsection{Parameters}

The parameters necessary for simulating SCORE process is practically the same with ones considered in simulating conventional column, the like of operating pressure of the column, operating temperature, number of stages, column specification and reboiler duty.

\subsection{Modeling}

The modeling of SCORE process with Hysys can be divided into seven (7) sections. These are feed conditioning, LNG exchanger, cold separator and the expander, absorber section, stripper section, reflux accumulator and its compressor, distillate column.

\subsection{Feed Conditioning}

The same feed conditioning for the convention column is also adopted here for the SCORE process, the inlet streams from well and dehydration unit are mixed and then expanded and thereafter it enters the LNG exchanger. Mixed feed operating conditions and their respective values are shown in Table 9.

Table 9. Mixed feed

\begin{tabular}{ll}
\hline Operating Conditions & Value \\
\hline Pressure (bar) & 30 \\
Temperature $\left({ }^{\circ} \mathrm{C}\right)$ & 24.87 \\
Molar flow (MMSCFD) & 6.989 \\
\hline
\end{tabular}




\subsection{LNG Exchanger}

Feed gas from mixer enters the LNG exchanger where the gas is to be cooled by heat exchange with the residue gas, the cold separator liquids, and the side reboiler stream, but these streams that will cool the inlet gas are not existing yet as at this stage of simulation, so a demo stream of cooling property will be used to achieve the expected aim and can then be deleted subsequently as the cooling streams emerged. The feed gas is cooled first by the demo stream and leaves the exchanger to cold separator at $8{ }^{\circ} \mathrm{C}$ and 30 bars.

\subsection{Cold Separator/Expander}

The gas is expanded first by a valve from 30 bars to 10 bars so as to enhance separation and as well reduce the work of the expander. The vapour phase from the top of separator enters the expander and the liquid stream from the bottom flow back to the LNG exchanger this serve as the first cooling stream from the process to support the demo stream.

The expander on the other hand expands the vapour stream from the separator to provide cooling for the process by reducing its pressure from 10 bars to 0.6 bars with working duty of $27.78 \mathrm{KW}$. The 2-phase expander outlet stream is fed to the tower at the bottom of the top (absorber) section.

\subsection{Absorber Section}

Recall that in the process description of SCORE process a reflux liquid will supply both the absorber and the stripper from the top and that this liquid is to be obtained from the overhead of the stripper but since the process has not been simulated to such extent, a demo stream of the reflux liquid property is simulated rich in methane and ethane. It is splitted into two equal parts by a Tee one to the top of the absorber and the other to the stripper.

Next step is to select the operating pressure. 4 bars and 0.6 bars were selected for both top and bottom pressures respectively, after several guess were made, before the case was resolved at the aforementioned pressures. Since condenser is not used, only one column specification needs to be defined to converge the column. However, some trials have to be done to find the best result. The simulation is continued to modeling the stripper section. Absorber operating conditions and their respective values are shown in Table 10.

Table 10. Absorber

\begin{tabular}{ll}
\hline Operating Conditions & Value \\
\hline Pressure of the top stage and bottom stage (bar) & $4,0.6$ \\
Temperature of the top stage and bottom stage & $-80,-140$ \\
$\left({ }^{\circ} \mathrm{C}\right)$ & 10 \\
Number of stages & Component recovery \\
Column specification & \\
\hline
\end{tabular}

\section{Stripper Section}

The other stream from the Tee enters the stripper at the top and the liquid draw from the bottom of the absorber enters the
LNG exchanger to provide further cooling and leave to the stripper at the top. The liquid from cold separator also enter the stripper at the middle of the column. Next is selecting the operating pressure at the top and the bottom of the column. After several guess, zero bar was used for the top and 10 bar as bottom pressure.

Three column specifications are required to converge the stripper column, they are; overhead product rate, bottom product rate and boil up ratio. Trials have to be done to find the best result. The same number of stages for the absorber is also used for the stripper. Operating conditions and their values are summarized in Table 11.

Table 11. Stripper

\begin{tabular}{ll}
\hline Operating Conditions & Value \\
\hline $\begin{array}{l}\text { Pressure of the top stage and bottom } \\
\text { stage (bar) }\end{array}$ & 0,10 \\
$\begin{array}{l}\text { Temperature of the top stage and } \\
\text { bottom stage }\left({ }^{\circ} \mathrm{C}\right)\end{array}$ & $23.49,81.02$ \\
Number of stages & 10 \\
Column specification & Component recovery, boil up ratio \\
Reboiler duty $(\mathrm{KW})$ & 129.2 \\
\hline
\end{tabular}

\section{Reflux Accumulator}

The simulation of this unit proves to be the most sensitive part of the whole process. It was discussed earlier that a demo stream was used as the reflux but at this stage the process is completely mature enough to provide all the streams it needs to run the plant itself. The streams from the top of both the absorber and stripper pass through the condenser to exchange heat, thereafter the stream from the stripper enters the accumulator which function is to separate the vapour from the liquid.

Vapour from the accumulator join the residue gas pipeline while the liquid is sent back to the Tee to replace the demo stream but the process did not simulate with ease, many balancing of properties between the liquid reflux and the demo stream was needed to run the process. See operating conditions and their respective values for reflux stream in Table 12.

Table 12. Reflux Stream

\begin{tabular}{ll}
\hline Operating Conditions & Value \\
\hline Vapour/phase fraction & 0.000 \\
Temperature $\left({ }^{\circ} \mathrm{C}\right)$ & -135.0 \\
Pressure (bar) & 3.783 \\
Molar flow (MMSCFD) & 4.091 \\
\hline
\end{tabular}

\section{Distillate Column}

Liquid from the bottom of the stripper enters this unit primarily to separate lighter hydrocarbon gas from the heavy hydrocarbons our desire product can thus be obtain with a measure of purity. The operating conditions of this column are summarized in the Table 13. 
Table 13. Distillate column

\begin{tabular}{ll}
\hline Operating Conditions & Value \\
\hline $\begin{array}{l}\text { Pressure of the top stage and bottom } \\
\text { stage (bar) }\end{array}$ & 4,10 \\
$\begin{array}{l}\text { Temperature of the top stage and } \\
\text { bottom stage }\left({ }^{\circ} \mathrm{C}\right)\end{array}$ & $17.46,209.6$ \\
Number of stages & 10 \\
Column specification & $\begin{array}{l}\text { Component fraction, bottom } \\
\text { product rate }\end{array}$ \\
Reboiler duty $(\mathrm{KW})$ & 4482 \\
\hline
\end{tabular}

\section{Equipment Cost Estimation}

It include fixed capital cost, working capital cost, operating cost, direct cost, utility cost and operating labor cost.

\section{Fixed Capital Cost}

It is made up of equipment purchase deliverance cost, installation of the purchased equipment cost, instrumentation and controls installed cost, and building and its services cost. It also have electrical systems installation cost, services facilities installed cost, engineering supervisions cost, construction expenses, yard improvement cost, contractor fees, legal expenses, and contingency.

\section{Working Capital}

This is needed capital to start up the plant and financing it for a period of time (in months), for plant to stabilize for money to flow in. The expenses that this capital covered is made up of salaries, raw materials, and contingencies. It is usually $3 \%$ of the capital cost, and will be recovered at the end of the project.

Total Investment - It is the sum of the fixed capital and working capital.

Operating Cost - it is all expenses incurred during the manufacturing, and made up of direct manufacturing cost, fixed manufacturing cost and general expenses.

Direct Cost - It is the costing of raw materials (NGL and steams)

Utility Cost - It is the costing of electricity for processing natural gas and cooling water pumping.

Operating Labor - it is the costing of work force required to operate the plant.

\subsection{Investment Analysis}

It is a measure of profitability of a project. The three parameters to be considered in other to determine profitability are internal rate of return (IRR), net present value (NPV), and pay-back period. It can be noted that operating cost, direct cost, utility cost and operating labor cost are not calculated in this work, because they depend on the capacity of the plant and may not be necessary in this work, as it is assumed to be the same for the two options. Fixed capital cost is enough to show the needed difference. Hence, investment analysis is not done.

\section{Results and Discussion}

Only the key unit operations result from the simulation vital to achieve the objective of this project will be shown*. The following unit operations results are vital;

Conventional Fractionation Process

- De-propanizer

- Butane Splitter

Single Column Overhead Recycle Process

- Liquid-Draw Splitter

Tables 14 and 15 are showing results 1 and 2 respectively for conventional column depropanizer, while other results for Hysys simulation are shown in the appendix. Also, Figures 7 and 8 in the appendix are showing the process flow sheet for conventional fractionation process and single column overhead recycle process respectively.

Table 14. Conventional Column Depropanizer Results 1.

\begin{tabular}{|c|c|}
\hline \multicolumn{2}{|l|}{ Flow Basis: Molar } \\
\hline \multicolumn{2}{|l|}{ Feed Composition } \\
\hline \multirow{2}{*}{ Flow Rate (MMSCFD) } & 34.4926 \\
\hline & $\mathrm{Mkl} ;$ m; \\
\hline Methane & 0.0000 \\
\hline Ethane & 0.0000 \\
\hline Propane & 0.4060 \\
\hline $\mathrm{i}$ - butane & 0.1616 \\
\hline $\mathrm{n}$ - butane & 0.1865 \\
\hline i - Pentane & 0.0732 \\
\hline $\mathrm{n}$-Pentane & 0.0568 \\
\hline n-Hexane & 0.0490 \\
\hline $\mathrm{n}$ - Heptane & 0.0306 \\
\hline $\mathrm{n}$ - Octane & 0.0219 \\
\hline $\mathrm{n}$ - Nonane & 0.0082 \\
\hline n - Decane & 0.0037 \\
\hline $\mathrm{n}-\mathrm{C}_{11}$ & 0.0019 \\
\hline $\mathrm{n}-\mathrm{C}_{12}$ & 0.0011 \\
\hline $\mathrm{n}-\mathrm{C}_{13}$ & 0.0003 \\
\hline $\mathrm{n}-\mathrm{C}_{14}$ & 0.0001 \\
\hline $\mathrm{n}-\mathrm{C}_{15}$ & 0.0001 \\
\hline $\mathrm{n}-\mathrm{C}_{16}$ & 0.0000 \\
\hline $\mathrm{H}_{2} \mathrm{O}$ & 0.0000 \\
\hline \multicolumn{2}{|l|}{ Flow Basis: Molar } \\
\hline \multicolumn{2}{|l|}{ Feed Flows } \\
\hline \multirow[t]{2}{*}{ Flow Rate (MMSCFD) } & 34.4926 \\
\hline & mkl,; m; \\
\hline Methane & 0.0000 \\
\hline Ethane & 0.0002 \\
\hline Propane & 13.9681 \\
\hline $\mathrm{i}$ - butane & 5.5735 \\
\hline $\mathrm{n}$ - butane & 6.4343 \\
\hline i - Pentane & 2.5247 \\
\hline $\mathrm{n}$ - Pentane & 1.9579 \\
\hline n - Hexane & 1.6898 \\
\hline $\mathrm{n}$ - Heptane & 1.0565 \\
\hline $\mathrm{n}$ - Octane & 0.7564 \\
\hline $\mathrm{n}$ - Nonane & 0.2829 \\
\hline n - Decane & 0.1279 \\
\hline $\mathrm{n}-\mathrm{C}_{11}$ & 0.0662 \\
\hline $\mathrm{n}-\mathrm{C}_{12}$ & 0.0372 \\
\hline $\mathrm{n}-\mathrm{C}_{13}$ & 0.0096 \\
\hline $\mathrm{n}-\mathrm{C}_{14}$ & 0.0040 \\
\hline $\mathrm{n}-\mathrm{C}_{15}$ & 0.0021 \\
\hline $\mathrm{n}-\mathrm{C}_{16}$ & 0.0011 \\
\hline $\mathrm{H}_{2} \mathrm{O}$ & 0.0000 \\
\hline
\end{tabular}


Table 15. Conventional Column Depropanizer Results 2.

\begin{tabular}{|c|c|c|}
\hline Products & & \\
\hline \multicolumn{3}{|l|}{ Flow Basis: Molar } \\
\hline \multicolumn{3}{|l|}{ Product Compositions } \\
\hline & $\mathrm{C}_{3}$ & $\mathrm{C}_{4}$ \\
\hline Flow Rate (MMSCFD) & 11.4949 & 23.0377 \\
\hline Methane & $\begin{array}{l}\mathrm{mkl}, ; \mathrm{m} ; \\
0.0000\end{array}$ & $\begin{array}{l}\mathrm{mkl}, ; \mathrm{m} ; \\
0.0000\end{array}$ \\
\hline Ethane & 0.0000 & 0.0000 \\
\hline Propane & 0.9753 & 0.1214 \\
\hline $\mathrm{i}$ - butane & 0.0216 & 0.2312 \\
\hline $\mathrm{n}$ - butane & 0.0031 & 0.2778 \\
\hline i - Pentane & 0.0000 & 0.1096 \\
\hline $\mathrm{n}$ - Pentane & 0.0000 & 0.0850 \\
\hline n - Hexane & 0.0000 & 0.0734 \\
\hline $\mathrm{n}$ - Heptane & 0.0000 & 0.0459 \\
\hline $\mathrm{n}$ - Octane & 0.0000 & 0.0328 \\
\hline $\mathrm{n}$ - Nonane & 0.0000 & 0.0123 \\
\hline n - Decane & 0.0000 & 0.0056 \\
\hline $\mathrm{n}-\mathrm{C}_{11}$ & 0.0000 & 0.0029 \\
\hline $\mathrm{n}-\mathrm{C}_{12}$ & 0.0000 & 0.0016 \\
\hline $\mathrm{n}-\mathrm{C}_{13}$ & 0.0000 & 0.0004 \\
\hline $\mathrm{n}-\mathrm{C}_{14}$ & 0.0000 & 0.0002 \\
\hline $\mathrm{n}-\mathrm{C}_{15}$ & 0.0000 & 0.0001 \\
\hline $\mathrm{n}-\mathrm{C}_{16}$ & 0.0000 & 0.0000 \\
\hline $\mathrm{H}_{2} \mathrm{O}$ & 0.0000 & 0.0000 \\
\hline \multicolumn{3}{|l|}{ Flow Basis: Molar } \\
\hline \multicolumn{3}{|l|}{ Product Flows } \\
\hline & $\mathrm{C}_{3}$ & $\mathrm{C}_{4}$ \\
\hline Flow Rate (MMSCFD) & 11.4949 & 23.0377 \\
\hline & $\mathrm{mkl} ;$; m; & $\mathrm{mkl}, ; \mathrm{m} ;$ \\
\hline Methane & 0.0000 & 0.0000 \\
\hline Ethane & 0.0002 & 0.0000 \\
\hline Propane & 11.1718 & 2.7963 \\
\hline $\mathrm{i}$ - butane & 0.2477 & 5.3259 \\
\hline $\mathrm{n}$ - butane & 0.0352 & 6.3991 \\
\hline i - Pentane & 0.0000 & 2.5247 \\
\hline $\mathrm{n}$ - Pentane & 0.0000 & 1.9579 \\
\hline n - Hexane & 0.0000 & 1.6898 \\
\hline $\mathrm{n}$ - Heptane & 0.0000 & 1.0565 \\
\hline $\mathrm{n}$ - Octane & 0.0000 & 0.7564 \\
\hline $\mathrm{n}$ - Nonane & 0.0000 & 0.2829 \\
\hline n - Decane & 0.0000 & 0.1279 \\
\hline $\mathrm{n}-\mathrm{C}_{11}$ & 0.0000 & 0.0662 \\
\hline $\mathrm{n}-\mathrm{C}_{12}$ & 0.0000 & 0.0372 \\
\hline $\mathrm{n}-\mathrm{C}_{13}$ & 0.0000 & 0.0096 \\
\hline $\mathrm{n}-\mathrm{C}_{14}$ & 0.0000 & 0.0040 \\
\hline $\mathrm{n}-\mathrm{C}_{15}$ & 0.0000 & 0.0021 \\
\hline $\mathrm{n}-\mathrm{C}_{16}$ & 0.0000 & 0.0011 \\
\hline $\mathrm{H}_{2} \mathrm{O}$ & 0.0000 & 0.0000 \\
\hline \multicolumn{3}{|l|}{ Flow Basis: Molar } \\
\hline \multicolumn{3}{|l|}{ Product Recoveries } \\
\hline & $\mathrm{C}_{3}$ & $\mathrm{C}_{4}$ \\
\hline Flow Rate (MMSCFD) & 11.4949 & 23.0377 \\
\hline & $\mathrm{mkl}, ; \mathrm{m} ;$ & $\mathrm{mkl}, ; \mathrm{m} ;$ \\
\hline Methane & 100.0000 & 0.0000 \\
\hline Ethane & 99.9990 & 0.0010 \\
\hline Propane & 79.9806 & 20.0194 \\
\hline $\mathrm{i}$ - butane & 4.4433 & 95.5567 \\
\hline $\mathrm{n}$ - butane & 0.5476 & 99.4524 \\
\hline i - Pentane & 0.0011 & 99.9989 \\
\hline $\mathrm{n}$ - Pentane & 0.0002 & 99.9998 \\
\hline $\mathrm{n}$ - Hexane & 0.0000 & 100.0000 \\
\hline
\end{tabular}

\begin{tabular}{lll}
\hline Products & & \\
\hline Flow Basis: Molar & & \\
\hline Product Compositions & $\mathrm{C}_{3}$ & $\mathbf{C}_{4}$ \\
\hline & 0.0000 & 100.0000 \\
\hline $\mathrm{n}-$ Heptane & 0.0000 & 100.0000 \\
$\mathrm{n}-$ Octane & 0.0000 & 100.0000 \\
$\mathrm{n}-$ Nonane & 0.0000 & 100.0000 \\
$\mathrm{n}-$ Decane & 0.0000 & 100.0000 \\
$\mathrm{n}-\mathrm{C}_{11}$ & 0.0000 & 100.0000 \\
$\mathrm{n}-\mathrm{C}_{12}$ & 0.0000 & 100.0000 \\
$\mathrm{n}-\mathrm{C}_{13}$ & 0.0000 & 100.0000 \\
$\mathrm{n}-\mathrm{C}_{14}$ & 0.0000 & 100.0000 \\
$\mathrm{n}-\mathrm{C}_{15}$ & 0.0000 & 100.0000 \\
$\mathrm{n}-\mathrm{C}_{16}$ & 100.0000 & 0.0000 \\
$\mathrm{H}_{2} \mathrm{O}$ & & \\
\hline
\end{tabular}

Sensitive to choosing the most economic option of LPG recovery between the conventional process and SCORE process is the recovery level of LPG from each of the options, total energy required and the cost of the equipment.

This will be analyzed based on the results of both options.

\subsection{Product Recovery}

Based on the simulation, the product recovery of the two options considered is tabulated below. Product recovery for the two options is shown in Table 16, while their product flows is shown in Table 17.

Table 16. Product Recovery

\begin{tabular}{lll}
\hline Composition (\%) & Conv. Process & SCORE Process \\
\hline Propane & 79.8695 & 99.9981 \\
i-butane & 90.0005 & 98.9988 \\
n-butane & 95.6441 & 92.5056 \\
\hline
\end{tabular}

Table 17. Product Flows

\begin{tabular}{lll}
\hline Composition [MMSCFD] & Conv. Process & SCORE Process \\
\hline Propane & 11.1650 & 20.0414 \\
i-butane & 4.7939 & 10.6055 \\
n-butane & 6.1188 & 18.6623 \\
\hline
\end{tabular}

\subsection{Equipment Duty}

Based on the simulation, the energy required of the two options considered is tabulated in Table 18 and 19 for conventional and SCORE processes respectively.

Table 18. Conventional process

\begin{tabular}{ll}
\hline Description & Duty [KW] \\
\hline De-ethanizer Reboiler & 5449 \\
De-butanizer Reboiler & 2735 \\
De-butanizer Condenser & 3391 \\
De-propanizer Reboiler & 129.2 \\
De-propanizer Condenser & 153.2 \\
Butane Splitter Reboiler & 117.3 \\
Butane Splitter Condenser & 145.6 \\
Total Energy Required & 12120.3 \\
\hline
\end{tabular}


Table 19. SCORE Process

\begin{tabular}{ll}
\hline Description & Duty [KW] \\
\hline Expander & 27.78 \\
Reflux Compressor & 4870 \\
Reflux Cooler & 5512 \\
Stripper Reboiler & 3511 \\
Distillation Reboiler & 4482 \\
Distillation Condenser & 3319 \\
Residue gas Compressor & 3200 \\
LNG-Exchanger & 328.6 \\
Total Energy Required & 25250.4 \\
\hline
\end{tabular}

NB: It should be noted that the reflux compressor and cooler are optional utilities if other method of liquefying the reflux stream is available. That been the case, total energy require of SCORE process will be $19828.4 \mathrm{KW}$.

The equipment cost is estimated to get an approximate price for the total plant installation. These calculations are based on given percentages. Major equipment costs are calculated in Appendix A. Tables 20 and 21 are showing equipment cost for conventional and SCORE processes respectively. Table 22 is showing the total investment for the two options, while Table 23 in the appendix is showing the fixed capital cost for the two options.

Table 20. Conventional process*

\begin{tabular}{ll}
\hline Equipment & Cost (\$) \\
\hline Column & 425571 \\
Tray & 60651.54 \\
Heat exchangers & 29157889.63 \\
Total Equipment Cost & 29644112.17 \\
\hline
\end{tabular}

* Equipment number: 4 columns, 109 column trays, 7 heat exchangers

Table 21. SCORE Process*

\begin{tabular}{ll}
\hline Equipment & Cost $\mathbf{( \$ )}$ \\
\hline Column & 319178.25 \\
Tray & 16693.1 \\
Heat exchangers & 24992476.83 \\
Separators & 136000.9 \\
Compressors & 105377.44 \\
Expander & 105377.44 \\
Total Equipment Cost & 25675104.21 \\
\hline
\end{tabular}

*Equipment number: 3 columns, 30 column trays, 6 heat exchangers, 2 separators; 1 compressor, 1 expander

Table 22. Total Investment

\begin{tabular}{lll}
\hline \multirow{2}{*}{ Investment } & \multicolumn{2}{l}{ Cost [MUSD(\$)] } \\
\cline { 2 - 3 } & Conventional Process & SCORE Process \\
\hline Fixed Capital & 149.90 & 129.52 \\
Working Capital & 4.50 & 3.89 \\
Total Investment & 154.40 & 133.41 \\
\hline
\end{tabular}

\section{Conclusions}

Today's major player in the World's market will be gas processors with performance of NGL/LPG recovery plant tailored to maximum product margins with higher efficient operation, and maintains it as the market conditions change. The comparative investigation done in this work is to highlight a process with higher flexibility, efficiency, reduced capital cost and higher product recovery.

From the analysis of the result, single column overhead recycle process (SCORE) has a total product recovery of $97.2 \%$ while conventional fractionation process has a total recovery of $88.5 \%$. Energy requirement margin between the SCORE process and conventional process is about $38.9 \%$, but in the same vein the fixed capital cost of SCORE process is cheaper compared to the conventional process. Sensitive to choosing the more economic option of LPG recovery between the conventional process and SCORE process is the recovery level of LPG from each of the options, total energy required and the cost of the equipment.

Based on the results of this study, the following conclusions can be drawn that both LPG extraction processes is profitable but it is more economical to use the Single Column Overhead Recycle process.

In SCORE process, configurations are available to provide maximum efficiency for a given product or to allow efficient adjustment of product recovery levels, if the product economy is viable and the market is boost for it. The process efficiency provided by the SCORE technology allows for processing LNG cargoes of varying composition with the same process design and nearly constant operating parameters. Also, it gives rooms for product variations with the same process design. These allows for more products in the market in terms of quantity and varieties to meet up the markets demand.

We recommend that more research should be made into modeling of single column overhead recycle process for better recovery of LPG. Also, the use of single column overhead recycle process for LPG extraction from NGL for both already established and new industries is recommended.

\section{Appendix}

\section{Equipment Cost}

Using the specifications of the equipment, quote from suppliers shows that almost the same price list is used for all the equipment [23].

\section{Conventional Fractionation Process}

Column: Each of the column cost $\$ 106393$ therefore 4 columns $=425571$

Tray: Each of the tray cost $\$ 557,109$ trays $=60651.54$

Heat exchangers: Each heat exchanger cost $\$ 4165413$,

7 exchangers $=29157889.63$ 
Table 23. Fixed Capital Cost for the Two Options

\begin{tabular}{lll}
\hline \multirow{2}{*}{ Fixed Capital Cost } & Cost [MUSD (\$)] & \\
\cline { 2 - 3 } & Conventional Process & SCORE Process \\
\hline Equipment Purchased Delivered & 29.64 & 25.68 \\
Installation of Equipment & 13.93 & 12.07 \\
Instrumentation and Controls Installed & 10.72 & 9.25 \\
Pipes Installations & 20.25 & 17.48 \\
Building and its services & 5.36 & 4.63 \\
Electrical Systems Installation & 3.28 & 2.82 \\
Services Facilities & 20.85 & 18.00 \\
Engineering and Supervisions & 9.83 & 8.48 \\
Construction Expenses & 12.21 & 10.54 \\
Yard Improvement & 2.98 & 2.57 \\
Contractor Fees & 6.56 & 5.66 \\
Legal Expenses & 1.19 & 1.03 \\
Contingency & 13.10 & 11.31 \\
Fixed Capital Investment & 149.90 & 129.52 \\
\hline
\end{tabular}

\section{Single Column Overhead Recycle Process (SCORE)}

Column: Each of the column cost $\$ 106393$ therefore 3 columns $=319178.25$

Tray: Each of the tray cost $\$ 557,30$ trays $=16693.1$

Heat exchangers: Each heat exchanger cost $\$ 4165413$,
6 exchangers $=24992476.83$

Separator: Each separator cost $\$ 68000.5,2$ separators $=$ 136000.9

Compressors/Expander: Each of this cost $\$ 105377.44,1$

Compressor $=\$ 105377.44$ and 1 Expander $=\$ 105377.44$

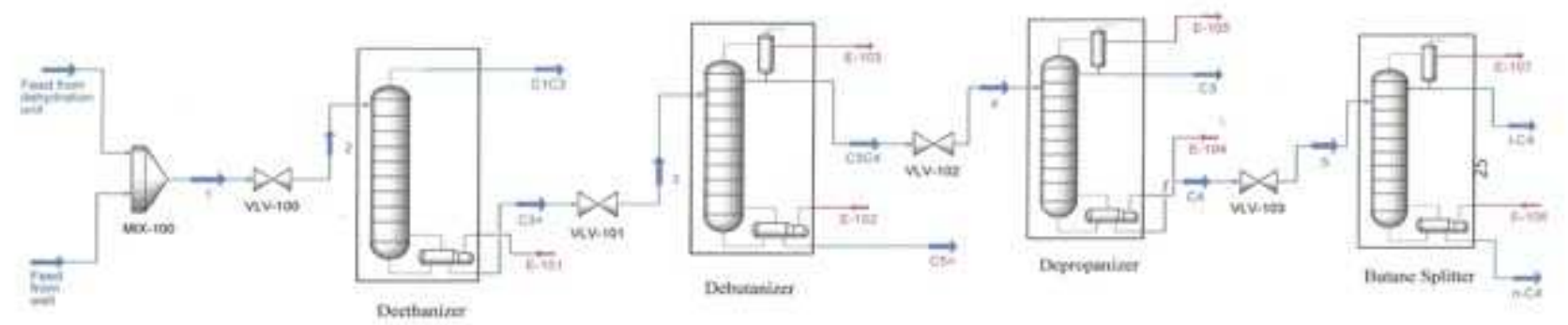

PSDSS MATERIAL STREAM SSSSS ENERGY STREAM $>S \$ S$ UNIT OPERATION

Figure 7. Conventional Process.

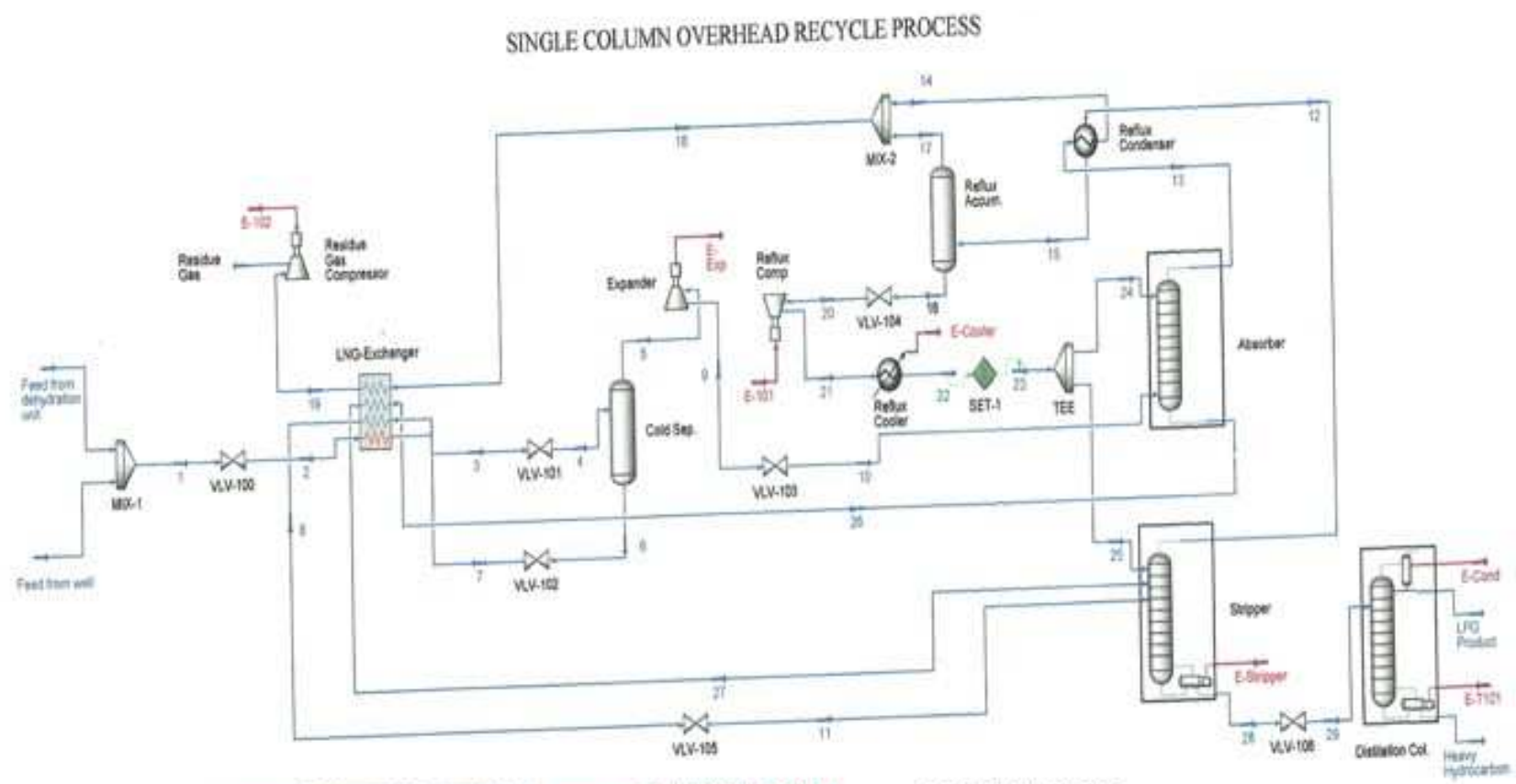

PSPS> MATERIAL STREAM $\gg>>>$ ENERGY STREAM $\gg \gg \gg>$ UNIT OPERATION

Figure 8. Single Column Overhead Recycle Process. 
Table 24. Hysys Conventional Column Depropanizer Result

\begin{tabular}{|c|c|c|c|c|c|c|}
\hline \multicolumn{7}{|c|}{ Distillation: Depropanizer } \\
\hline \multicolumn{7}{|c|}{ SUMMARY } \\
\hline & $\mathrm{C}_{3}$ & \multicolumn{5}{|l|}{$\mathrm{C}_{4}$} \\
\hline i-Pentane (\%) & 0.0011 & \multicolumn{5}{|l|}{99.9989} \\
\hline n-Pentane (\%) & 0.0002 & \multicolumn{5}{|l|}{99.9998} \\
\hline n-Hexane (\%) & 0.0000 & \multicolumn{5}{|l|}{100.0000} \\
\hline n-Heptane (\%) & 0.0000 & \multicolumn{5}{|l|}{100.0000} \\
\hline n-Octane (\%) & 0.0000 & \multicolumn{5}{|l|}{100.0000} \\
\hline n-Nonane (\%) & 0.0000 & \multicolumn{5}{|l|}{100.0000} \\
\hline n-Decane (\%) & 0.0000 & \multicolumn{5}{|l|}{100.0000} \\
\hline$n-C_{11}(\%)$ & 0.0000 & \multicolumn{5}{|l|}{100.0000} \\
\hline$n-C_{12}(\%)$ & 0.0000 & \multicolumn{5}{|l|}{100.0000} \\
\hline $\mathrm{n}-\mathrm{C}_{13}(\%)$ & 0.0000 & \multicolumn{5}{|l|}{100.0000} \\
\hline$n-C_{14}(\%)$ & 0.0000 & \multicolumn{5}{|l|}{100.0000} \\
\hline $\mathrm{n}-\mathrm{C}_{15}(\%)$ & 0.0000 & \multicolumn{5}{|l|}{100.0000} \\
\hline $\mathrm{n}-\mathrm{C}_{16}(\%)$ & 0.0000 & \multicolumn{5}{|l|}{100.0000} \\
\hline $\mathrm{H}_{2} \mathrm{O}(\%)$ & 100.0000 & \multicolumn{5}{|l|}{0.0000} \\
\hline \multicolumn{7}{|c|}{ COLUMN PROFILES } \\
\hline Reflux Ratio: 2.167 & Reboil Ratio: 0.9999 & & The Flow Option & ected & Flow Basis: $\mathrm{N}$ & \\
\hline Column Profile Flov & & & & & & \\
\hline & Temperature $\left({ }^{\circ} \mathrm{C}\right)$ & Pressure (KPa) & $\begin{array}{l}\text { Net liquid } \\
\text { (Kgmole/h) }\end{array}$ & $\begin{array}{l}\text { Net Vapor } \\
\text { (Kgmole/h) }\end{array}$ & $\begin{array}{l}\text { Net Feed } \\
(\text { Kgmole/h) }\end{array}$ & $\begin{array}{l}\text { Net Draws } \\
(\text { Kgmole/h) }\end{array}$ \\
\hline Condenser & 23.49 & 900.0 & 24.82 & $\mathrm{mkl}, ; \mathrm{m} ;$ & $\mathrm{mkl} ; ; \mathrm{m} ;$ & 11.45 \\
\hline 1-Main TS & 24.40 & 900.0 & 24.53 & 36.28 & $\mathrm{mkl}, ; \mathrm{m} ;$ & $\mathrm{mkl} ; ; \mathrm{m} ;$ \\
\hline 2-Main TS & 26.04 & 905.9 & 24.17 & 35.98 & $\mathrm{mkl}, ; \mathrm{m} ;$ & $\mathrm{mkl}, ; \mathrm{m} ;$ \\
\hline 3-Main TS & 28.29 & 911.8 & 23.69 & 35.62 & $\mathrm{mkl}, ; \mathrm{m} ;$ & $\mathrm{mkl}, ; \mathrm{m} ;$ \\
\hline 4-Main TS & 31.22 & 917.6 & 23.13 & 35.15 & $\mathrm{mkl}, ; \mathrm{m} ;$ & $\mathrm{mkl}, ; \mathrm{m} ;$ \\
\hline 5-Main TS & 34.74 & 923.5 & 22.52 & 34.59 & $\mathrm{mkl} ;$;m; & $\mathrm{mkl}, ; \mathrm{m} ;$ \\
\hline 6-Main TS & 38.73 & 929.4 & 21.76 & 33.97 & $\mathrm{mkl}, ; \mathrm{m} ;$ & $\mathrm{mkl}, ; \mathrm{m} ;$ \\
\hline 7-Main TS & 43.56 & 935.3 & 20.12 & 33.22 & $\mathrm{mkl}, ; \mathrm{m} ;$ & $\mathrm{mkl}, ; \mathrm{m} ;$ \\
\hline 8-Main TS & 53.04 & 941.2 & 45.94 & 31.57 & 34.49 & $\mathrm{mkl}, ; \mathrm{m} ;$ \\
\hline 9-Main TS & 53.32 & 947.1 & 46.03 & 22.90 & $\mathrm{mkl}, ; \mathrm{m} ;$ & mkl,;m; \\
\hline 10-Main TS & 53.63 & 952.9 & 46.12 & 22.99 & mkl,;m; & $\mathrm{mkl}, ; \mathrm{m} ;$ \\
\hline 11-Main TS & 54.00 & 958.8 & 46.21 & 23.08 & $\mathrm{mkl} ;$;m; & $\mathrm{mkl}, ; \mathrm{m} ;$ \\
\hline 12-Main TS & 54.46 & 964.7 & 46.30 & 23.17 & $\mathrm{mkl}, ; \mathrm{m} ;$ & $\mathrm{mkl} ; ; \mathrm{m} ;$ \\
\hline 13-Main TS & 55.08 & 970.6 & 46.39 & 23.26 & mkl,;m; & $\mathrm{mkl}, ; \mathrm{m} ;$ \\
\hline 14-Main TS & 55.98 & 976.5 & 46.47 & 23.35 & $\mathrm{mkl}, ; \mathrm{m} ;$ & mkl,;m; \\
\hline 15-Main TS & 57.36 & 982.4 & 46.56 & 23.44 & $\mathrm{mkl}, ; \mathrm{m} ;$ & mkl,;m; \\
\hline 16-Main TS & 59.53 & 988.2 & 46.65 & 23.52 & $\mathrm{mkl}, ; \mathrm{m} ;$ & $\mathrm{mkl}, ; \mathrm{m} ;$ \\
\hline 17-Main TS & 62.94 & 994.1 & 46.69 & 23.61 & $\mathrm{mkl}, ; \mathrm{m} ;$ & mkl,;m; \\
\hline 18-Main TS & 68.58 & 1000 & 46.07 & 23.65 & $\mathrm{mkl}, ; \mathrm{m} ;$ & $\mathrm{mkl}, ; \mathrm{m} ;$ \\
\hline Reboiler & 81.09 & 1000 & $\mathrm{mkl}, ; \mathrm{m} ;$ & 23.04 & $\mathrm{mkl}, ; \mathrm{m} ;$ & 23.04 \\
\hline Column Profiles En & & & & & & \\
\hline & & Temperature $\left({ }^{\circ} \mathrm{C}\right)$ & $\begin{array}{l}\text { Liquid Enthalpy } \\
\text { (KJ/Kgmol) }\end{array}$ & Vapor Enthal & (KJ/Kgmole) & Heat Loss $(\mathrm{KJ} / \mathrm{h})$ \\
\hline Condenser & & 23.49 & $-1.211 \mathrm{e}+005$ & $-1.035 e+005$ & & mkl,;m; \\
\hline 1-Main TS & & 24.40 & $-1.220 \mathrm{e}+005$ & $-1.058 \mathrm{e}+005$ & & $\mathrm{mkl}, ; \mathrm{m} ;$ \\
\hline 2-Main TS & & 26.04 & $-1.233 e+005$ & $-1.064 \mathrm{e}+005$ & & $\mathrm{mkl}, ; \mathrm{m} ;$ \\
\hline 3-Main TS & & 28.29 & $-1.251 \mathrm{e}+005$ & $-1.071 \mathrm{e}+005$ & & mkl,;m; \\
\hline 4-Main TS & & 31.22 & $-1.273 e+005$ & $-1.081 \mathrm{e}+005$ & & $\mathrm{mkl}, ; \mathrm{m} ;$ \\
\hline 5-Main TS & & 34.74 & $-1.296 \mathrm{e}+005$ & $-1.092 \mathrm{e}+005$ & & $\mathrm{mkl}, ; \mathrm{m} ;$ \\
\hline 6-Main TS & & 38.73 & $-1.320 \mathrm{e}+005$ & $-1.105 e+005$ & & $\mathrm{mkl}, ; \mathrm{m} ;$ \\
\hline 7-Main TS & & 43.56 & $-1.351 \mathrm{e}+005$ & $-1.116 \mathrm{e}+005$ & & $\mathrm{mkl}, ; \mathrm{m} ;$ \\
\hline 8-Main TS & & 53.04 & $-1.445 \mathrm{e}+005$ & $-1.125 \mathrm{e}+005$ & & $\mathrm{mkl}, ; \mathrm{m} ;$ \\
\hline 9-Main TS & & 53.32 & $-1.445 \mathrm{e}+005$ & $-1.125 \mathrm{e}+005$ & & $\mathrm{mkl}, ; \mathrm{m} ;$ \\
\hline 10-Main TS & & 53.63 & $-1.444 \mathrm{e}+005$ & $-1.125 \mathrm{e}+005$ & & $\mathrm{mkl}, ; \mathrm{m} ;$ \\
\hline 11-Main TS & & 54.00 & $-1.444 e+005$ & $-1.126 e+005$ & & mkl,;m; \\
\hline
\end{tabular}


Table 25. Hysys Conventional Column Butane Spliter Result

\begin{tabular}{|c|c|c|c|c|c|c|}
\hline \multicolumn{7}{|c|}{ Distillation: Butane Splitter } \\
\hline \multicolumn{7}{|c|}{ SUMMARY } \\
\hline & $\mathrm{i}-\mathrm{C}_{4}$ & \multicolumn{5}{|l|}{$\mathrm{n}-\mathrm{C}_{4}$} \\
\hline i-Pentane (\%) & 0.5859 & \multicolumn{5}{|l|}{99.4141} \\
\hline n-Pentane (\%) & 0.3218 & \multicolumn{5}{|l|}{99.6782} \\
\hline n-Hexane (\%) & 0.0303 & \multicolumn{5}{|l|}{99.9697} \\
\hline n-Heptane (\%) & 0.0032 & \multicolumn{5}{|l|}{99.9968} \\
\hline n-Octane (\%) & 0.0004 & \multicolumn{5}{|l|}{99.9996} \\
\hline n-Nonane (\%) & 0.0000 & \multicolumn{5}{|l|}{100.0000} \\
\hline n-Decane (\%) & 0.0000 & \multicolumn{5}{|l|}{100.0000} \\
\hline$n-C_{11}(\%)$ & 0.0000 & \multicolumn{5}{|l|}{100.0000} \\
\hline $\mathrm{n}-\mathrm{C}_{12}(\%)$ & 0.0000 & \multicolumn{5}{|l|}{100.0000} \\
\hline $\mathrm{n}-\mathrm{C}_{13}(\%)$ & 0.0000 & \multicolumn{5}{|l|}{100.0000} \\
\hline $\mathrm{n}-\mathrm{C}_{14}(\%)$ & 0.0000 & \multicolumn{5}{|l|}{100.0000} \\
\hline $\mathrm{n}-\mathrm{C}_{15}(\%)$ & 0.0000 & \multicolumn{5}{|l|}{100.0000} \\
\hline $\mathrm{n}-\mathrm{C}_{16}(\%)$ & 0.0000 & \multicolumn{5}{|l|}{100.0000} \\
\hline $\mathrm{H}_{2} \mathrm{O}(\%)$ & 100.0000 & \multicolumn{5}{|l|}{0.0000} \\
\hline \multicolumn{7}{|c|}{ COLUMN PROFILES } \\
\hline Reflux Ratio: 6.878 & Reboil Ratio: 1.0000 & & The Flow Option & lected & Flow Basis: & \\
\hline Column Profile Flow & & & & & & \\
\hline & Temperature $\left({ }^{\circ} \mathrm{C}\right)$ & Pressure (KPa) & $\begin{array}{l}\text { Net liquid } \\
(\text { Kgmole/h) }\end{array}$ & $\begin{array}{l}\text { Net Vapor } \\
(\text { Kgmole/h) }\end{array}$ & $\begin{array}{l}\text { Net Feed } \\
(\text { Kgmole/h) }\end{array}$ & $\begin{array}{l}\text { Net Draws } \\
(\text { Kgmole/h) }\end{array}$ \\
\hline Condenser & 0.6579 & 400.0 & 24.90 & $\mathrm{mkl}, ; \mathrm{m} ;$ & $\mathrm{mkl}, ; \mathrm{m} ;$ & 3.620 \\
\hline 1-Main TS & 9.819 & 400.0 & 22.37 & 28.52 & $\mathrm{mkl}, ; \mathrm{m} ;$ & $\mathrm{mkl}, ; \mathrm{m} ;$ \\
\hline 2-Main TS & 27.88 & 405.9 & 36.37 & 25.99 & 23.04 & mkl,;m; \\
\hline 3-Main TS & 29.60 & 411.8 & 36.53 & 16.95 & $\mathrm{mkl} ;$;m; & $\mathrm{mkl}, ; \mathrm{m} ;$ \\
\hline 4-Main TS & 31.70 & 417.6 & 36.73 & 17.11 & $\mathrm{mkl}, ; \mathrm{m} ;$ & $\mathrm{mkl}, ; \mathrm{m} ;$ \\
\hline 5-Main TS & 34.13 & 423.5 & 36.97 & 17.31 & $\mathrm{mkl}, ; \mathrm{m} ;$ & mkl,;m; \\
\hline 6-Main TS & 36.77 & 429.4 & 37.25 & 17.55 & $\mathrm{mkl}, ; \mathrm{m} ;$ & $\mathrm{mkl}, ; \mathrm{m} ;$ \\
\hline 7-Main TS & 39.42 & 435.3 & 37.57 & 17.84 & $\mathrm{mkl}, ; \mathrm{m} ;$ & mkl,;m; \\
\hline 8-Main TS & 41.88 & 441.2 & 37.89 & 18.15 & $\mathrm{mkl}, ; \mathrm{m} ;$ & $\mathrm{mkl}, ; \mathrm{m} ;$ \\
\hline 9-Main TS & 44.04 & 447.1 & 38.20 & 18.47 & $\mathrm{mkl}, ; \mathrm{m} ;$ & $\mathrm{mkl}, ; \mathrm{m} ;$ \\
\hline 10-Main TS & 45.83 & 452.9 & 38.48 & 18.78 & $\mathrm{mkl}, ; \mathrm{m} ;$ & mkl,;m; \\
\hline 11-Main TS & 47.29 & 458.8 & 38.72 & 19.06 & $\mathrm{mkl}, ; \mathrm{m} ;$ & mkl,;m; \\
\hline 12-Main TS & 48.48 & 464.7 & 38.93 & 19.30 & $\mathrm{mkl}, ; \mathrm{m} ;$ & mkl,;m; \\
\hline 13-Main TS & 49.46 & 470.6 & 39.11 & 19.51 & $\mathrm{mkl}, ; \mathrm{m} ;$ & mkl,;m; \\
\hline 14-Main TS & 50.32 & 476.5 & 39.26 & 19.69 & $\mathrm{mkl}, ; \mathrm{m} ;$ & mkl,;m; \\
\hline 15-Main TS & 51.12 & 482.4 & 39.39 & 19.84 & $\mathrm{mkl}, ; \mathrm{m} ;$ & $\mathrm{mkl}, ; \mathrm{m} ;$ \\
\hline 16-Main TS & 51.95 & 488.2 & 39.49 & 19.98 & $\mathrm{mkl}, ; \mathrm{m} ;$ & mkl,;m; \\
\hline 17-Main TS & 53.06 & 494.1 & 39.47 & 20.07 & $\mathrm{mkl}, ; \mathrm{m} ;$ & mkl,;m; \\
\hline 18-Main TS & 55.23 & 500.0 & 38.84 & 20.05 & mkl,;m; & mkl,;m; \\
\hline Reboiler & 63.14 & 500.0 & $\mathrm{mkl}, ; \mathrm{m} ;$ & 19.42 & $\mathrm{mkl}, ; \mathrm{m} ;$ & 19.42 \\
\hline Column Profiles Ene & & & & & & \\
\hline & & Temperature $\left({ }^{\circ} \mathrm{C}\right)$ & $\begin{array}{l}\text { Liquid Enthalpy } \\
\text { (KJ/Kgmole) }\end{array}$ & Vapor Enthal & KJ/Kgmole) & $\begin{array}{l}\text { Heat Loss } \\
(\mathrm{KJ} / \mathrm{h})\end{array}$ \\
\hline Condenser & & 0.6579 & $-1.306 \mathrm{e}+005$ & $-1.088 \mathrm{e}+005$ & & $\mathrm{mkl}, ; \mathrm{m} ;$ \\
\hline 1-Main TS & & 9.819 & $-1.388 \mathrm{e}+005$ & $-1.122 \mathrm{e}+005$ & & $\mathrm{mkl} ; \mathrm{m} ;$ \\
\hline 2-Main TS & & 27.88 & $-1.555 \mathrm{e}+005$ & $-1.175 e+005$ & & mkl,;m; \\
\hline 3-Main TS & & 29.60 & $-1.558 \mathrm{e}+005$ & $-1.183 e+005$ & & $\mathrm{mkl}, ; \mathrm{m} ;$ \\
\hline 4-Main TS & & 31.70 & $-1.563 e+005$ & $-1.194 \mathrm{e}+005$ & & $\mathrm{mkl} ; \mathrm{m} ;$ \\
\hline 5-Main TS & & 34.13 & $-1.568 \mathrm{e}+005$ & $-1.208 \mathrm{e}+005$ & & $\mathrm{mkl} ; \mathrm{m} ;$ \\
\hline 6-Main TS & & 36.77 & $-1.574 \mathrm{e}+005$ & $-1.224 \mathrm{e}+005$ & & $\mathrm{mkl}, ; \mathrm{m} ;$ \\
\hline 7-Main TS & & 39.42 & $-1.579 \mathrm{e}+005$ & $-1.242 \mathrm{e}+005$ & & $\mathrm{mkl} ; \mathrm{m} ;$ \\
\hline 8-Main TS & & 41.88 & $-1.584 \mathrm{e}+005$ & $-1.258 \mathrm{e}+005$ & & $\mathrm{mkl}, ; \mathrm{m} ;$ \\
\hline 9-Main TS & & 44.04 & $-1.587 \mathrm{e}+005$ & $-1.273 \mathrm{e}+005$ & & $\mathrm{mkl}, ; \mathrm{m} ;$ \\
\hline 10-Main TS & & 45.83 & $-1.589 \mathrm{e}+005$ & $-1.285 \mathrm{e}+005$ & & $\mathrm{mkl} ; \mathrm{m} ;$ \\
\hline 11-Main TS & & 47.29 & $-1.590 \mathrm{e}+005$ & $-1.293 \mathrm{e}+005$ & & $\mathrm{mkl}, ; \mathrm{m} ;$ \\
\hline
\end{tabular}




\section{References}

[1] Wikipedia the Free Encyclopedia, en.wikipedia.org/wiki/LPG, 2010.

[2] M. R. Fenske, "Fractionation of straight-run Pennsylvania gasoline", Ind. Eng. Chem., Vol.24 Pp. 482, 1932.

[3] R. M. Ahmad, A. Majed, E. D. H. Osama, S. F. Marcos, and M. Amir - Usman, "Fractionation of Natural Gas Liquids to produce LPG" TPG4140 Natural Gas, Norway, 2011.

[4] K. Eldar, F. Feby and S. Juejing, "Process Design and Economic Investigation of LPG Production from Natural Gas Liquids (NGL)" TKP4170 Process design, Norway, 2010.

[5] Wikipedia the Free Encyclopedia: en.wikipedia.org/wiki/LPG-subtilis. 2012.

[6] Petroleum Fuel Facilities. MIL-HDBK-1022A, Department of defense of the United States, 1999, p. 34.

[7] J. D. Wilkinson, H. M. Hudson, K. T. Cuellar, and R.N. Pitman, "Next Generation Processes for NGL/LPG Recovery", Proceedings of the 77th GPA Annual Convention, pp 1-8, 2002.

[8] J. D. Wilkinson and H. M. Hudson, U.S., Patent No. 7,155,931, 2002.

[9] J. D. Wilkinson, H. M. Hudson and K. T. Cuellar, U.S., Patent Application Nos. 11/144,728; 60/810,244; and 60/812,686, 2002.

[10] A.C. Christiansen, S. Skogestad and K. Lien, "Complex Distillation Arrangements: Extending the Petlyuk ideas", Computers and Chem. Engr., Pp. 21, Suppl., S237-S242. (Supplement from symposium PSE-97/ESCAPE-7, Trondheim, Norway, pp. 25-29, 1997.

[11] A.C. Christiansen, S. Skogestad and K. Lien, "Partitioned Petlyuk arrangements for quaternary separations", Proc. Symposium Distillation and Absorption 97, Published by I Chem. E, UK. Maastricht, Netherlands. Pp. 745-756, 1997.

[12] M. Peters and K. Timmerhaus, "Plant Design and Economics for Chemical Engineers", Fourth Edition, McGraw-Hill International, New York, Pp. 910, 1991.

[13] E. R. Gilliland, "Optimum feed-plate composition in multicomponent rectification", Ind. Eng. Chem., Vol.32 Pp. 918, 1940.

[14] N. Grant and M. Santa, "LNG Fractionation Process and Optimization of the Turbo expander Unit", Proceedings of the 82nd GPA Annual Convention, Pp. 1-7, 2008.

[15] T. Richard, B. Richard, W. Wallace and A. S. Joseph, "Analysis, Synthesis, and Design of Chemical Processes", Third Edition. Prentice Hall, Pp. 1088, 2008.

[16] I. J. Halvorson and S. Skogestad, "Distillation Theory", from http://www.nt.ntnu.no/users/skoge/publications/1999/Distillati onTheory/original/distillationtheory.pdf

[17] J. W. Holmes, M. L. Spears and J.A. Bullin, "Sweetening LPGs with Amines," Chemical Engineering Progress Conf. http://www.opisnet.com/methodology.asp\#nglforwards 1984.

[18] S. Parkash, "Petroleum fuels manufacturing", McGraw-Hill, New York, Pp. 3-11, 2003.

[19] Wikipedia the Free Encyclopedia, en.wikipedia.org/wiki/NGL, 2012.

[20] T. James, S. Phil, and M. Erin, "Natural Gas Processing: The Crucial Link between Natural Gas Production and Its Transportation to Market, Energy Information Administration, Office of Oil and Gas", 2006.

[21] Argus NGL Americans Methodology from http://web04.us.argusmedia.com/ArgusStaticContent//Meth/N GL\%20AmericasMeth-Latest.pdf

[22] Petroleum Fuel Facilities, MIL-HDBK-1022A, Department of defense of the United States, Pp. 34, 1999.

[23] K.T. Cuellar, H.M. Hudson, and J.D. Wilkinson, "Economical Options for Recovering NGL/LPG at LNG Receiving Terminals", Proceedings of the 86th GPA Annual Convention, Pp. 2-10, 2007.

[24] CME prices from http://www.cmegroup.com/trading/energy/petrochemicals/mnt -belvieuiso-butane-5-decimal-opis-swap futures_quotes_settlements_futures.htm 2010. 